\title{
APLIKASI KERAMIK PADA FUNGSI AROMATHERAPY
}

\author{
Noor Sudiyati *)
}

\begin{abstract}
Aromatherapy obtained through combustion of essential oil as the need of health is now mushrooming in big cities. Essential oil that made of plants has the ability to create relaxation without causing any side effect. Those herbal such as roses, ginger, jasmine, lemon grass and so on are growing around us and treated with distilled technology.

Essential oils can be processed into liquid, stick, and solid, and its use requires a ceramic container made of clay. Ceramics is capable to answer the needs of aromatherapy furnace with such a wide variety of themes, images, expressions and artistic decorations.

Frangipani themed ceramic furnace is made for aromatherapy containers used for essential liquids that are heated with candles burning. This furnace made with incorporated slab techniques so it has unique character.
\end{abstract}

Key words: Ceramic, Aromatherapy, Herbal theme, aromatherapy, for firing, frangipaniceramic.

\section{ABSTRAKSI}

Kebutuhan akan kesehatan melalui system pembakaran mintak atsiri disebut aromatherapy yang berasal dari herbal marak di kota-kota besar, Minyak atsiri yang terbuat dari tumbuh-tumbuhan ternyata mampu membuat rileksasi, dipakai tanpa meninggalkan efek samping. Herbal itu banyak tumbuh di sekeliling kita, namun diolah dengan teknologi suling, misalnya saja: bunga kenanga, melati (jasmine), sere, Jahe, mawar dan lain sebagainya.

Minyak atsiri (aromatherapy) bisa diolah sehingga dapat berupa cairan, stick, dan padat, dalam penggunaanya memerlukan wadah berupa keramik yang terbuat dari Tanah liat. Keramik mampu menjawab kebutuhan wadah pembakaran atau tungku aromatherapi dengan berbagai macam: tema, imaji, ekpresi dan dekorasi yang artistic.

Tungku Keramik bertema Kamboja dibuat untuk wadah aromatherapy yang dipakai untuk atsiri cairan yang dipanaskan dengan pembakaran lilin. Tungku ini dibuat dengan teknik slab yang digabungkan, menjadi tungku yang berkarakter khas.

Kata Kunci: keramik, aromatherapy, herbal, pemanasan, tema kamboja.

\footnotetext{
* Noor Sudiyati (keramiknoor@yahoo.com), Staf Pengajar Program Studi Kriya Seni, Jurusan Kriya, Fakultas Seni Rupa, Institut Seni Indonesia Yogyakarta
} 


\section{PENDAHULUAN}

Suasanya menjadi nyaman dan atmosfir harum menyelinap diseluruh ruangan, kemudian atmosfir tersebut terhirup dan menjadikanya semakin menentramkan. Begitu terus menghirup aroma yang dikeluarkan dari therapy minyak atsiri, pikiran benar-benar menjadi tenang, saat istirahat yang didambakan semakin nyata terlaksana, tiba-tiba saja sudah terlelap tidur, ketika bangun badan merasa segar kembali. Dengan bantuan aromatherapy istirahat kita menjadi berkualitas dan benar-benar menyenangkan. Ketika raga kita sudah lelah seharian bekerja, rasanya perlu memiliki kebijakan terhadap diri sendiri untuk sekedar memanjakan diri dengan istirahat yang berkualitas. Istirahat yang dibarengi dengan wewangian aromatherapy menjadi trend saat ini, gaya istirahat ini dapat menyegarkan kembali badan seketika setelah terlelap tidur, dihantarkan oleh aroma wangi yang ditimbulkan dari minyak atsiri yang dipanaskan dengan suhu sedikit panas.

\section{PEMBAHASAN}

\section{Jenis Aromatherapy}

Aromatherapy yang digunakan adalah minyak atsiri yang berasal dari jasmine. Minyak ini mengandung daya rileksasi dan sensasi tenang untuk menghantarkan seseorang untuk istirahat tidur, pada waktu-waktu dirasa badan lelah memerlukan asupan energy lagi maka solusi yang kini banyak dicari adalah menggunakan sarana aromatherapy. Sedangkan bunga kenanga berwarna kuning dipercaya dapat mengobati sakit kuning (hepatitis) lantaran bunganya mengandung alfa-kariofilena yang memberikan reaksi pengendalian gangguan hati yang kuat.( Syasul Hidayat: 2008. 40) Zat yang dibuat dari herbal ini memiliki daya bantu positif untuk mengundang sensasi nyaman yang membantu pikiran menjadi relax, maka biasanya proses menggunakan aromatherapy untuk istirahat ini juga kadang disebut dengan rilaxsasi. Penggunaan aromatherapy untuk menghantarkan pada proses tidur adalah cara yang sangat aman dan efektif, tidak memerlukan beaya yang banyak layaknya membeli obat tidur bagi orang yang mengalami susah tidur. Aromatherapy untuk membantu istirahat tidur dan untuk menyegarkan kembali badan ini sekarang banyak dicari dan menjadi trend masyarakat di perkotaan.

Cara rileksasi ini banyak ditempuh oleh ibu-ibu atau wanita pekerja yang memerlukan enersi kembali lagi pada tubuh, agar kelelahan cepat hilang dan mendapatkan kesegaran badan kembali, sangat praktis dan cara ini penuh estetika, untuk lebih dapat menikmati estetika yang lebih lagi bisa dilakukan di tempat-tempat spa, di salon-salon yang menyediakan jasa spa, di tempat tersebut dapat mendapatkan jasa pijat untuk melemaskan otot-otot agar kembalai segar bugar. Aromatherapy menjadi bahan yang sangat penting bagi gerai-gerai spa, dan kalau dilihat dari berbagai macam desain-desain jasa rileksasi dengan aromatherapy sangat menarik dan memiliki daya pikat yang tinggi, sehingga banyak para ibu yang menghabiskan sedikit waktu dan uangnya pada kegiatan-kegiatan ini. Terutama di 
hari-hari libur banyak salon untuk jasa ini dipenuhi oleh para konsumennya.

Setelah terasa badan kembali segar biasanya seseorang ingin kembali lagi untuk mengulang cara rileksasi tersebut. Namun rileksasi itu sebenarnya bisa dilakukan dirumah, dengan menggunakan bantuan bahan aromatherapy sehingga tidak memerlukan ongkos untuk jasa pijat, cukup dengan menyalakan lilin untuk membakar cairan aroma, banyak pilihan aroma yang ditawarkan dengan berbagai macam harum bau wewangian herbal, tinggal pilih yang sesuai dengan selera kita dan kebutuhannya. Pilihan aroma herbal disesuaikan dengan kebutuhan. Ada aroma yang membantu untuk mengurangi stress, ada aroma khusus untuk menenangkan, ada aroma untuk rileksasi agar tubuh cepat tidur, dan ada juga aromatherapy penghilang sakit amnesia. Herbal yang digunakan adalah herbal yang banyak tumbuh disekelilig kita, sederhana, namun pengolahan yang modern membuat herbal itu memiliki nilai dan manfaatnya yang dapat diberdayakan secara tepat dan efektif.

Rileksasi dengan herbal sebenarnya sudah dilakukan oleh orang jaman dahulu, apalagi di China yang sangat terkenal akan pengobatan tradisinya, herbal sangat dipercaya untuk mendampingi kesehatan manusia, demikian dengan obat-obat herbal China. Apalagi obat yang berasala dari herbal murni tak akan mengakibatkan efek samping negative terhadap tubuh. (Tanujaya: 2011. 18). Bahan aromatherapy berasal dari sari minyak herbal yang disebut atsiri, bahan pokoknya tanaman herbal yang diambil dari: batangnya, daunnya maupun bunganya, tumbuhtumbuhan itu dari berbagai macam jenis, yang ada di sekeliling kita yang banyak tumbuh di Asia, dan Indonesia misalnya: bunga kenanga, bunga melati, kemangi, kayu manis, jeruk, jahe, sere, cengkeh, dan lain sebagainya. Bahan-bahan ini diambil minyak atau sarinya dengan cara disuling. Biasanya hasil dari herbal ini berupa cairan, Dipasaran cairan ini sudah dicampur lagi dengan bahan lain (tidak murni seratus persen). Disamping itu ada juga aromatherapy yang berbentuk padat, biasanya berupa stik dan kerucut (cone). Penggunaan dari bentuk padat maupun cair biasanya menggunakan wadah yang berbeda, pada aroma cairan perlu wadah yang memiliki cekung sedangkan untuk bentuk Cone bisa memerlukan wadah yang rata dengan desain-desain yang bebas, lain lagi yang berbentuk stick memerlukan wadah yang berlobang untuk menaruh stick yang berbentuk kecil memanjang, sehingga wadah untuk aroma stick ini memerlukan perhitungan desain agar berfungsi dengan baik dan tepat. Gambar perbedaan keramik untuk stick, cone dan cairan).

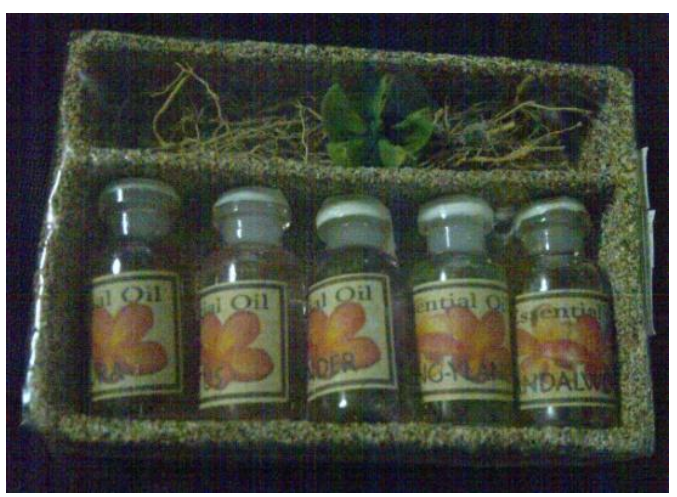

Gambar.1 Jenis aromatherapy yang ada di pasaran 


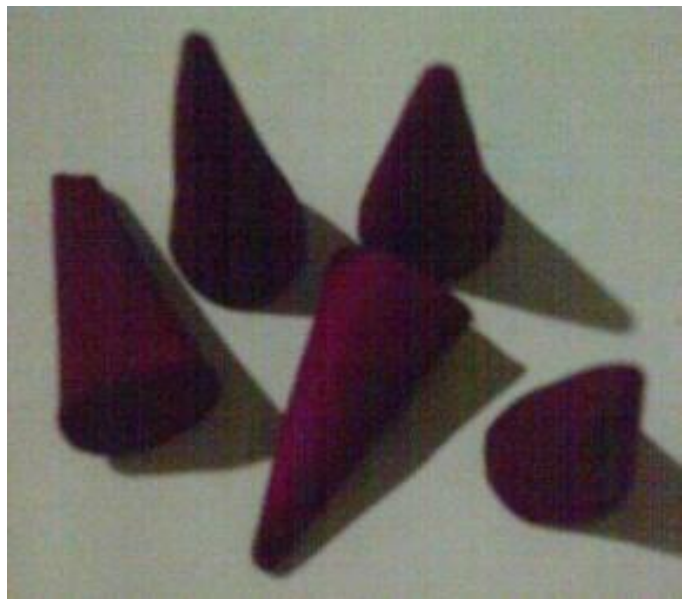

Gambar 2. Jenis Aromatherapy padat (Stick)

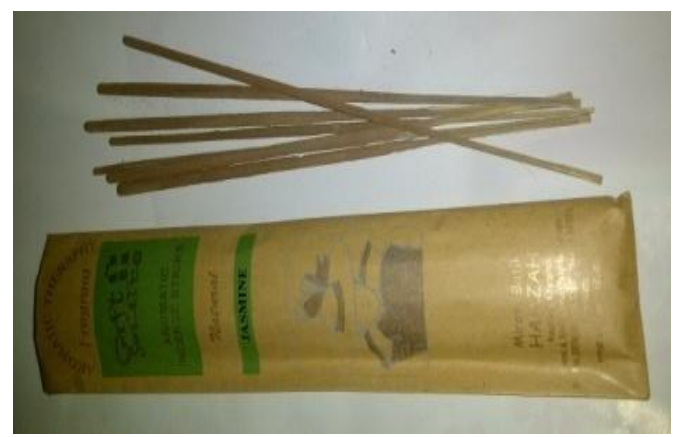

Gambar 3. Jenis Aromatherapy bentuk padat memanjang (Stick)

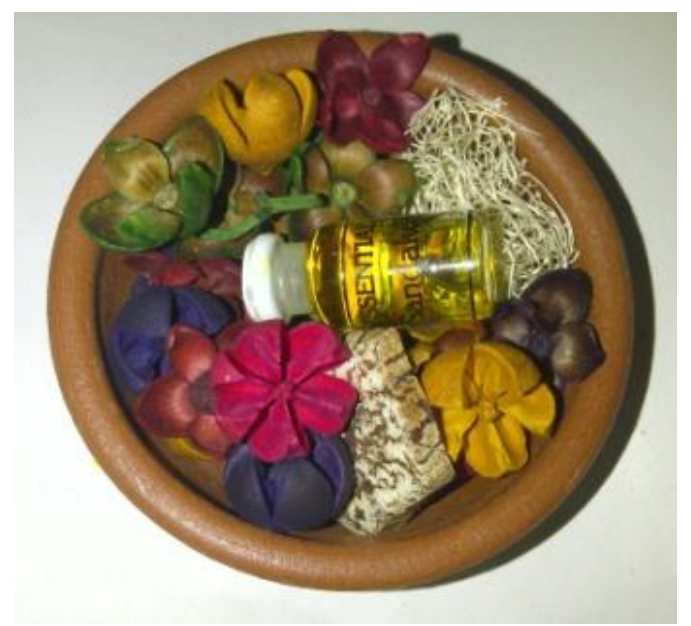

Gambar 4. Jenis Aromatherapy Potpoury Dari buah jenis kayu yang ditetesi dengan minyak atsiri

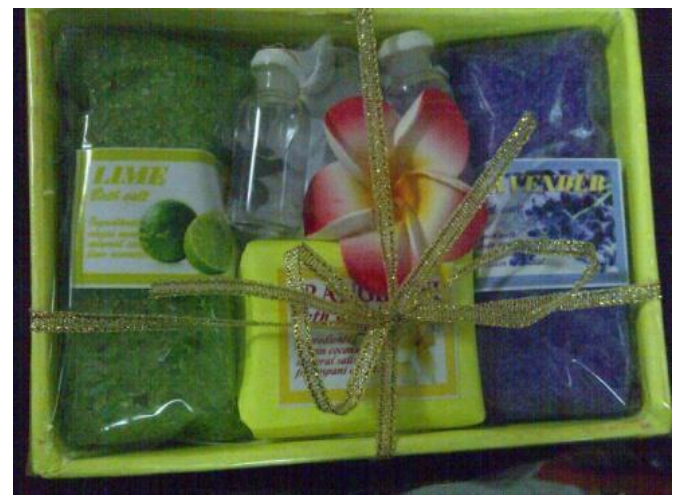

Gambar 5. Jenis Garam kesehatan yang ada di pasaran Fungsinya untuk mandi

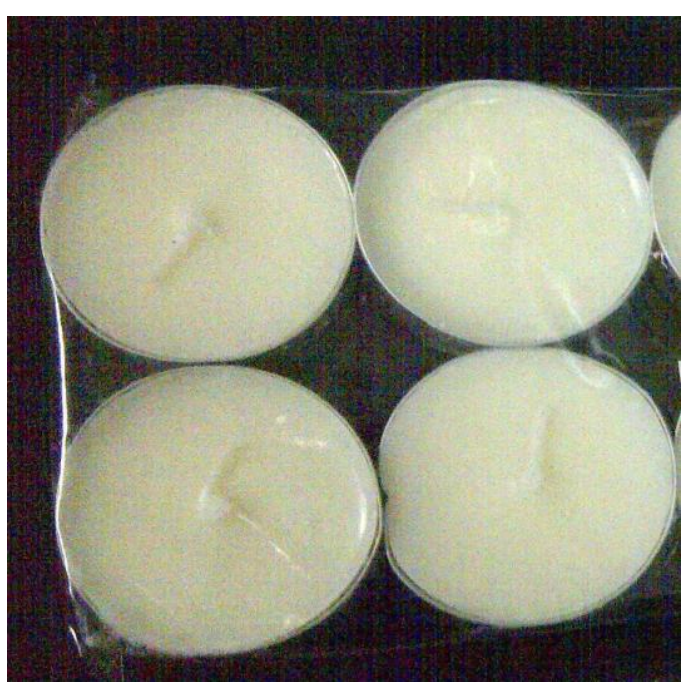

Gambar 6. Lilin dalam Aluminium voil

Untuk memanasi Aromatherapy

Ada juga aromatherapy yang mewujudkannya dengan dicampurkan pada lilin, pembentukannya dengan cara dicetak setelah lilin dicairkan. Cara ini bisa ditempuh dan divisualkan dengan beragam bentuk dan desain yang beraneka macam serta warna yang beragam, untuk jenis ini cairan aroma dicampurkan dengan lilin yang dipanaskan hingga mencair dan mendidih, kemudian diberi warna, seterusnya dicetak menurut rencana dan desainnya. Hasil dari system cetak sangat beragam dan sangat luas, bahkan bisa dibentuk bunga, hewan, serta bentuk yang 
lucu-lucu yang sangat menarik bagi konsumen. Kalau kita amati jenis aroma therapy lilin ini banyak dipasarkan di Bali, $\mathrm{P}$ Dewata sebagai tempat wisata atau di tempat-tempat wisata yang banyak hotel dan rumah spa sebagai yang tidak pernah sepi pengunjung. Lilin aroma banyak juga dijual di gerai-gerai spa, rumah sehat, gallery craft, dan butik serta di hotelhotel.
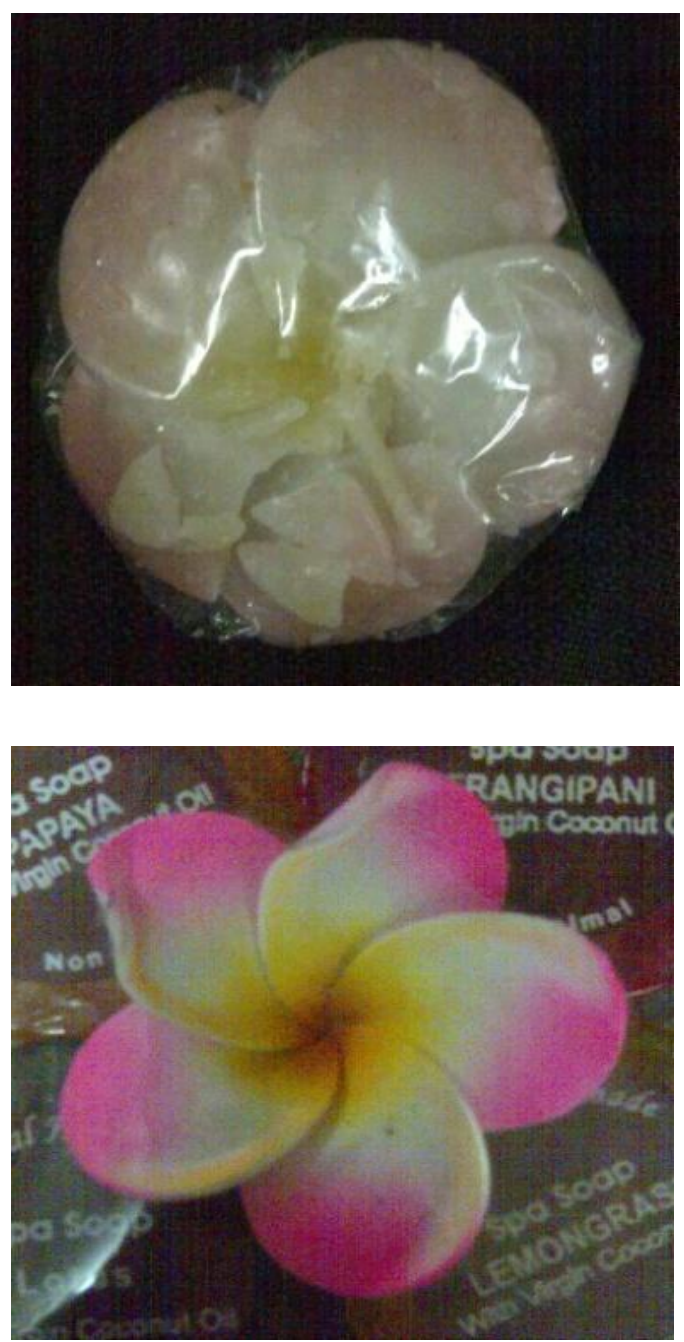

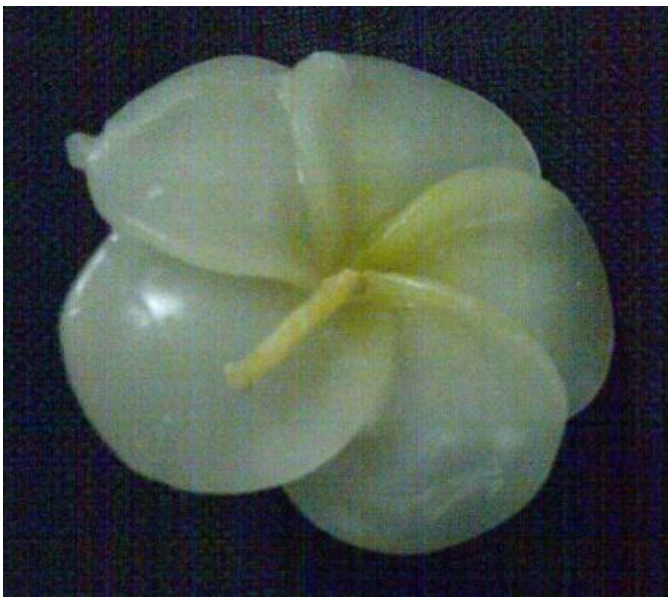

Gambar 7a, b, c. Lilin yang dibuat dicetak bentuk bunga kamboja.

Minyak Atsiri merupakan anti microbial alami yang dapat membunuh bakteri, virus, jamur. Mengenai ini telah banyak dilakukan penelitian. Efek samping penggunaan minyak atsiri dalam aromatherapy jarang ditemukan.( Koensumariah: 2009.7 lyang berbentuk cairan lebih memudahkan penggunaanya, yakni dicampur dengan air kemudian dipanaskan dengan suhu yang tidak terlalu panas, biasanya pemanasan minyak aromatherapy dengan lilin yang diwadahi oleh aluminium voil, pemanasan minyak dicampur dengan air yang sudah matang. Pemilihan air matang agar cairan yang sudah tercampur aroma tinggal memanaskan, tidak perlu mendidihkan kembali, dan air akan lebih awet penggunaannya. Posisi lilin yang memanasi berada dibawah air, maka konstruksi wadah untuk menampung air berada dibagian atas. Aluminium voil yang berisi lilin dalam penggunaannya dinyalakan untuk memanasi minyak atsiri ketika lilin nyala memanasi bagian wadah diatas. Nyala lilin berkisar antara 3 sampai 6 jam, dengan durasi tersebut perkiraan pengguna sudah lelap tidur, kemudian 
minyak atsiri diatasnya juga berangsur angsur habis.

\section{KERAMIK SEBAGAI WADAH AROMA THERAPY}

Banyak desain-desain unik untuk wadah cairan dibuat dengan berbagai macam model, sebagai wadah untuk pembakaran lilin sering disebut sebagai tungku. yang menguntungkan wadah aromateraphy dari keramik karena bahan tanah liat sebagai material dapat dibentuk dalam berbagai macam desain, berbagai macam ukuran, dan berbagai macam style yang memiliki imajinasi sangat luas. Nilai lebih dari tanah akan muncul setelah disentuh dengan imajinasi dan teknik oleh pengeramik, tanah liat akan memberikan respon sesuai dengan yang diberikan, bentuk juga akan terjadi sesuai dengan kehendaknya. ( Stepen Trimble: 1993).

Banyak kemungkinan bentuk dan gaya keramik yang sedang trend dengan mudah divisualkan untuk kebutuhan fungsi aroma ini. Keuntungan memakai tungku keramik yang berbahan tanah liat ini bisa dibuat dalam berbagai macam ukuran, kepentingan, tema, dan lain-lain. Dengan material tanah liat yang memiliki sifat plastis dan mudah digarap, ide-ide dapat divisualkan dengan mudah. (Noor Sudiyat: 2010. 99).Tungku aroma therapy dapat mewadai bahan aroma yang berbentuk: cairan, stick maupun cone, karena tungku dari keramik berglasir dapat menjaga cairan tidak merembes dan memurnikan aroma dari cairan atsirinya.

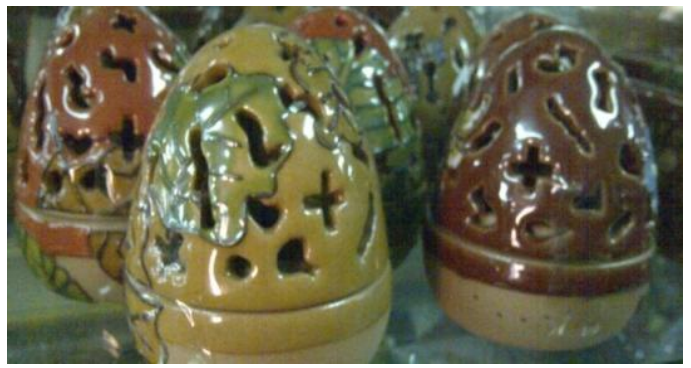

Gambar. 8. Wadah aromatherapy (Tungku) untuk bentuk cone. Keramik buatan Dewata keramik

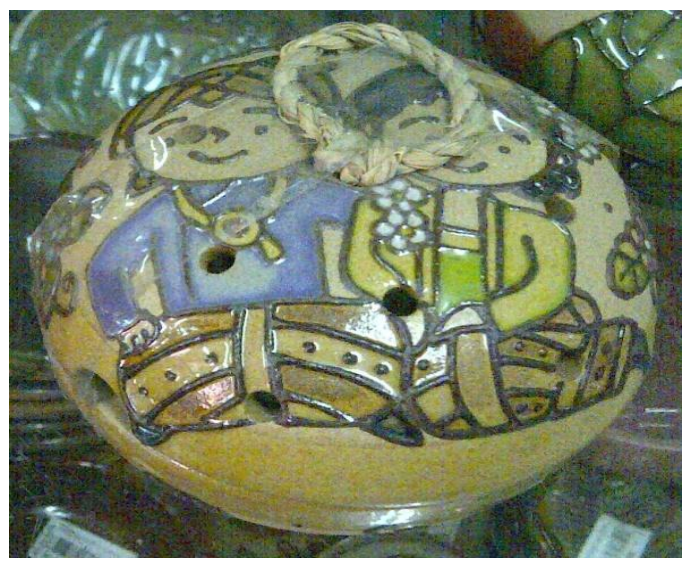

Gambar 9. Tungku keramik untuk aromatherapy bentuk stick Keramik buatan: dewata keramik

Visual keramik untuk wadah minyak atsiri dapat diwujudkan dengan berbagai macam teknik pembentukan, terbuka dalam berbagai macam desain, terutama keramik untuk desain-desain yang berdekorasi, sehingga untuk menyuguhkan estetika pada penggunaan aromatherapy dapat dicapai pada estetika apapun. Keramik juga bisa menjawab apabila membutuhkan desain tungku harus beraplikasi dengan suatu tema yang ditentukan, dapat pula dilakukan berbagai macam dekorasi yang mengarah pada beberapa tema, baik dengan imajinasi warna glasirnya maupun hiasan ornamentasinya yang berupa: goresan, cap, maupun tempelan/tambahan. Pembentukan keramik adakalanya mengandung ekspresi, ekspresi dalam 
pembuatan keramik bisa juga dicapai melaluipembentukan hand building, yaitu pembentukan dengan tangan langsung. Sentuhan-sentuhan alat, campuran unsureunsur bahan yang dipakai disertai gejolak, tekanan emosi si senimannya didukung oleh teknologi penerapan glasir dan jenis glasirnya, serta system pembakaranya akan menampilkan ekspresi pada visualisasi keramik. (Noor Sudiyati: 2004. 29).

Berbagai macam desain bentuk tungku dapat dibangun lewat media keramik dengan teknik yang beragam, misalnya saja teknik putar yang banyak menghasilkan barang-barang silindris, dengan outline yang sederhana hingga garis sensasional. Teknik slab memberikan visual bentuk yang geometris, kokoh dan mempunyai kesan tegas, lugas. Adapun pembentukan dengan teknik cetak baik cetak tekan maupun cetak tuang dapat menguntungkan karena dapat melipatgandakan produk dengan waktu yang relatif singkat. Ada juga teknik penggabungan dari beberapa teknik dengan berbagai bagian yang akan memberikan bentuk-bentuk artistic.

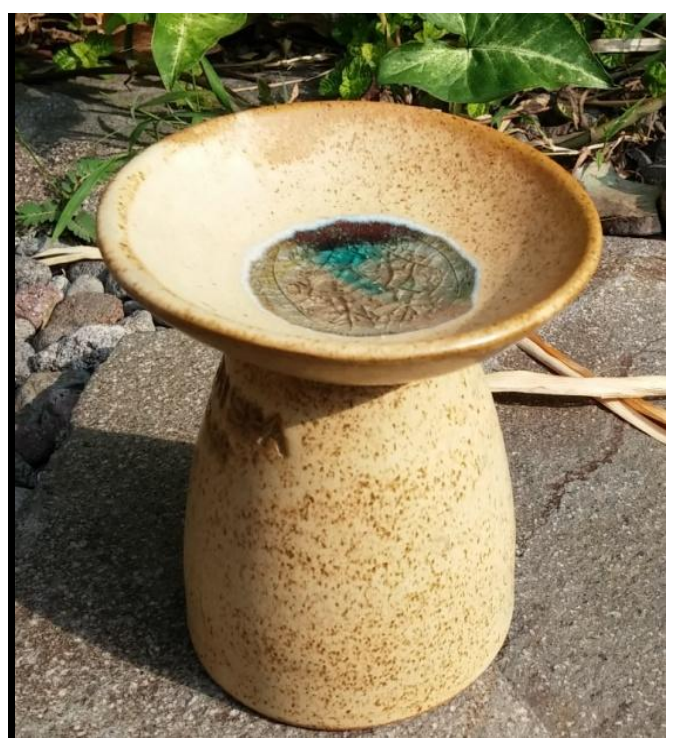

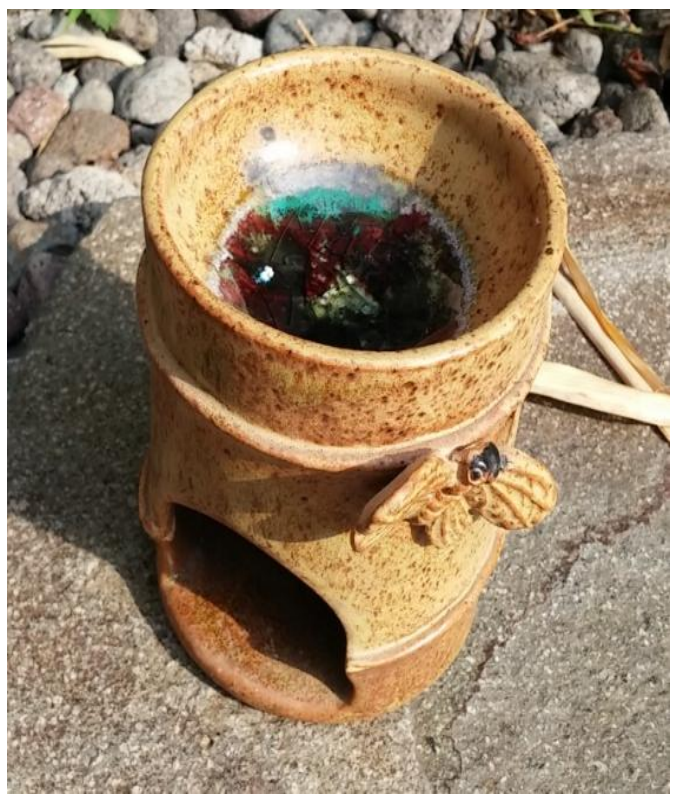

Gambar 10, 11. Keramik tungku Aromatherapy Keramik tungku Aromatherapy Dibuat dengan teknik putar dibuat dengan teknik putar Desain Keramik: Noor Sudiyati Desain Keramik: Noor Sudiyati

Bentuk wadah (keramik) yang diolah permukaanya dapat menambah estetika, dekorasi, imajinasi tekstur lembut, tegas, berirama, kasar, dan goresan figure-figur, baik flora maupun fauna atau abstrak dapat dilakukan dengan berbagai cara antara lain dengan: ditempel, dipres cetakan, dengan goresan, maupun dengan glasir yang dapat memberikan berbagai imajinasi serta keindahankeindahan yang lain, bahkan tidak terduga. Dari teknik yang digunakan untuk pembuatan keramiknya kadang menjadikan wujud keramik aromatherapy memiliki nilai yang sangat tinggi setelah dipergunakan atau diaplikasi dengan fungsinya (untuk mewadai aroma therapy).

Secara keseluruhan bentuk dari tungku aromatherapy memiliki bagianbagian yang berfungsi, bagian bawah adalah ruangan untuk menaruh lilin sebagai pemanas, ruangan tersebut 
disediakan lubang untuk memasukkan lilinnya, sedangkan bagian atasnya harus memiliki tempat yang mencekung sebagai wadah cairan. Antara besaran wadah bagian atas harus sesuai dengan bawahnya, juga antara ruang bawah sebaiknya diperhitungkan seberapa kapasitas ruangan agar bisa menyimpan lilin dengan leluasa untuk memasukkan atau mengeluarkan aluminium bekas lilinnya. Sedangkan bagian atas sebagai wadah penampung sebaiknya memiliki standart kecekungan yang dapat menampung cairan dengan aman, diperhitungkan untuk dapat menampung cairan yang habis dalam beberapa jam ( 6 jam) ketika dipanaskan, sehingga dalam waktu yang diperlukan aroma tersebut bereaksi hingga menidurkan penggunanya, setelah kemudian baru cairan habis.

\section{DESAIN KERAMIK UNTUK} AROMATHERAPY

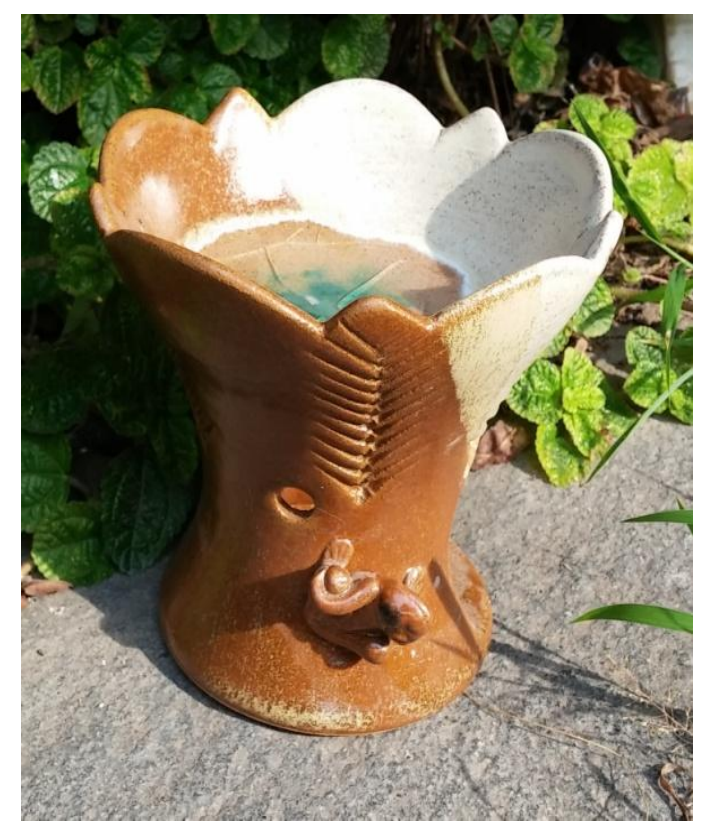

Gambar 12. Desain Keramik Noor Sudiyati

Teknik: putar, Tema : Daun Thn 2005

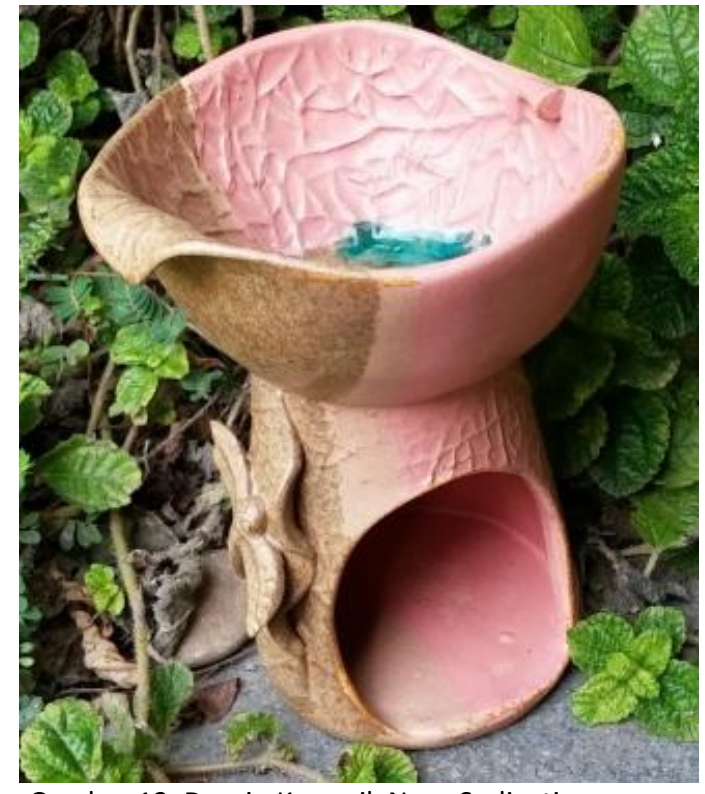

Gambar 13. Desain Keramik Noor Sudiyati

Teknik: putar, Tema : Daun , Thn 2005.

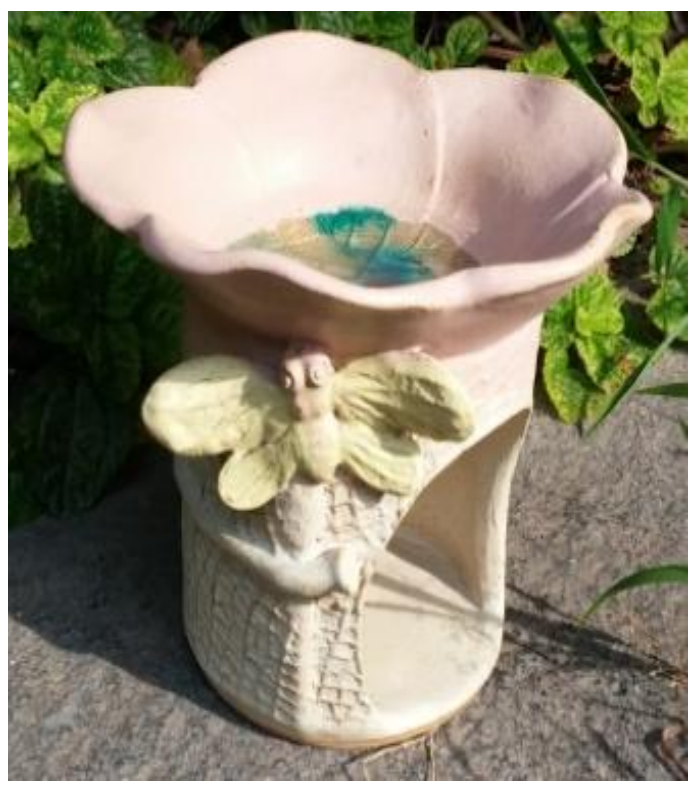

Gambar 14. Keramik Tungku romatherapy

Desain: Noor Sudiyati, Teknik cetak gabungan, Tahun 2003 


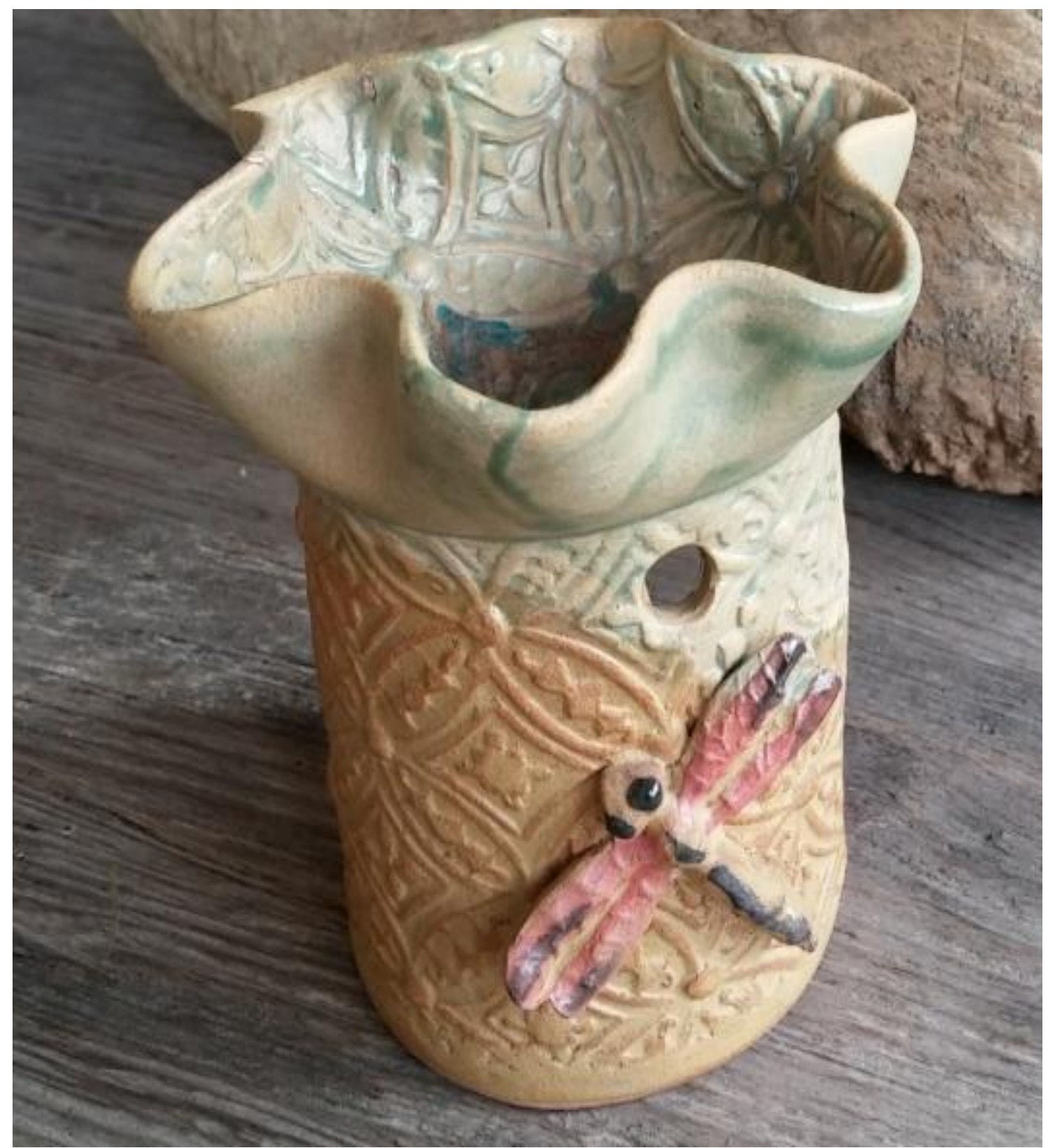

Gambar15. Keramik Tungku Aromatherapy, Desain: Noor Sudiyati, Teknik cetak gabungan, Tahun 2003

\section{KERAMIK TUNGKU TEMA KAMBOJA UNTUK AROMATHERAPY}

Ide Kamboja

Kamboja merupakan jenis tanaman tahunan yang tumbuh dengan struktur banyak cabang dan membentuk diri sebagai sebuah pohon yang bertajuk bulat dan besar. Tingginya dapat mencapai 8-10 meter, sedangkan usianya bisa mencapai ratusan tahun di habitat tumbuh beriklim tropis. (Don WS dkk: 2002 p. 40).

Pohon kamboja bisa tumbuh besar dan pesat, menyamai pohon atau tanaman keras, namun kamboja termasuk rumpun 
Plumeria, bernama latin Plumeria acuminate (Iswoyo : 1987. 75). Bunga kamboja yang kita kenal dengan bunga Jepun memiliki keindahan yang abadi, baunya harum, dengan karakter yang kuat dan sangat khas. Batangnya menggoreskan artistic bentuk pohon yang berkesan sacral, di Jawa pohon ini banyak tumbuh di arena makam yang berada di desa-desa. Daun dari kamboja bergaris beraturan dengan tekstur yang tajam kuat membujur dari tangkai terus ke ujung daun. Bunga banyak memiliki warna yang serasi dari: kuning ke putih, merah maron ke ping, dan ping ke putih, indah warnanya. Kesan yang ditampilkan pada tumbuhan kamboja artistic dan abadi, artistic yang unik setiap saat terselip pada telinga gadis Bali menari. Jepun mengimajinasikan masyarakat Bali atas berbagai upacara dan ritual tradisi dalam budaya Bali. Di Bali bunga kamboja menempati posisi yang tinggi, biasanya ditanam di halaman pura. Bunganya yang putih bersih dan halus banyak dijadikan bunga persembahan kepada Sang Hyang Widhi Wasa, ataupun diselipkan diatas telinga. ( Isworo: 1987.77).

Untuk memvisualisaaikan desain tungku bertema kamboja yang telah dibuat, pertama-tama adalah menentukan ukuran dari pada tungku keseluruhan. Pertimbangan fungsi yang harus diperhatikan bahwa tungku tersebut memiliki fungsi sebagai wadah, dan juga sebagai tempat api (lilin yang dinyalakan). Kapasitas ruang untuk cairan yang diperlukan harus dapat menampung cairan $50 \mathrm{ml}$, dengan posisi berada di atas.

\section{Proses kerja}

1. Persiapan Tanah Plastis

2. Pembuatan Lembaran (slab) dari tanah liat

3. Pembuatan pola untuk bagian-bagian pembentukan

4. Pembuatan cetakan dari gips

5. Pembentukan pada cetakan

6. Penggabungan bagian-bagiannya

7. Pembuatan lubang pada body (untuk udara dan masuk/keluar lilin)

8. Pengeringan

9. Pembakaran

10. Pengglasiran

11. Pembakaran Glasir

\section{Keterangan Gambar}

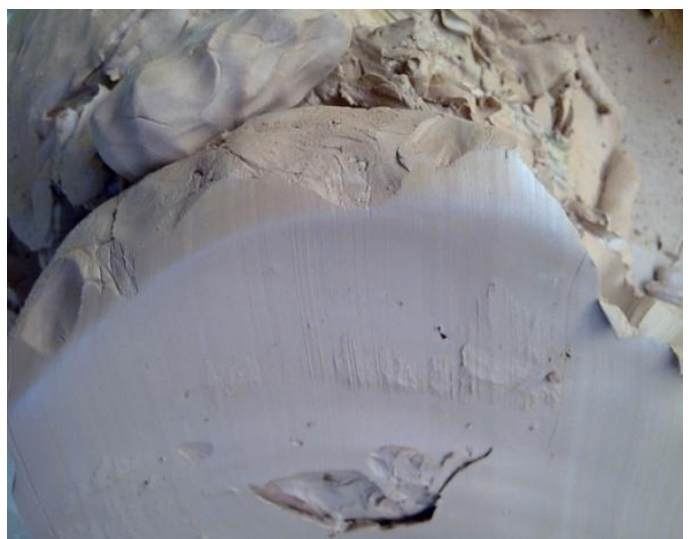

Gambar 16. Tanah liat plastis sebagai bahan dasar keramik

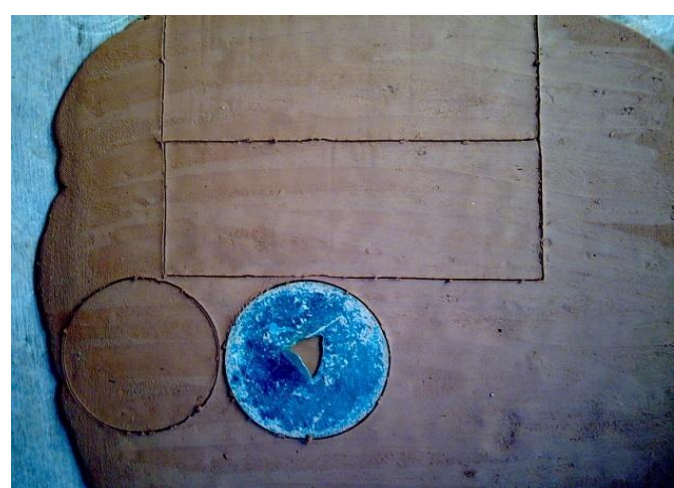

Gambar 17. Membuat ukuran pada tanah liat plastis 


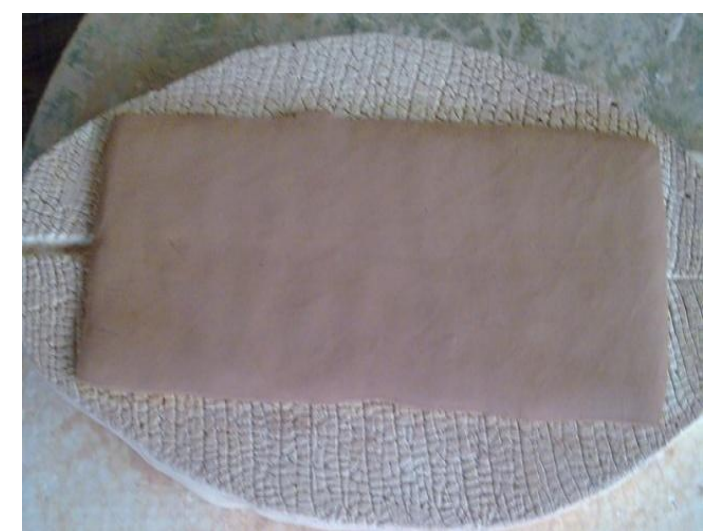

Gambar 18. Lembaran Tanah liat ditekankan pada Cetakan

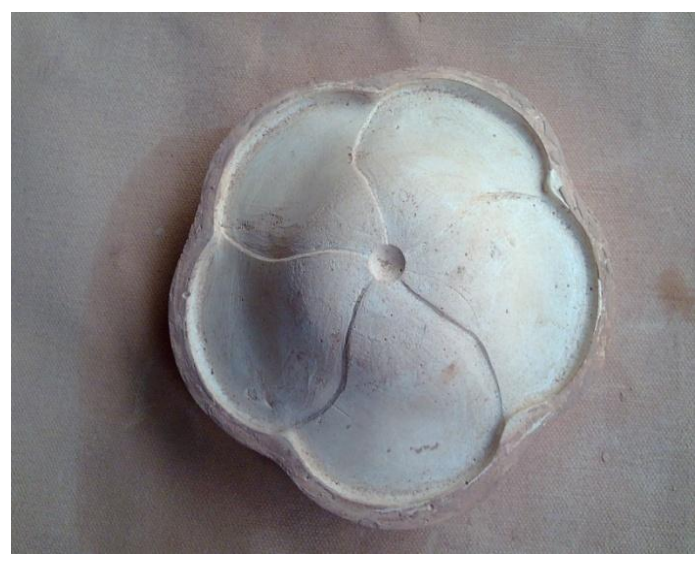

Gambar 19. Cetakan bentuk bunga bagian atas dari tungku Terbuat dari Gips

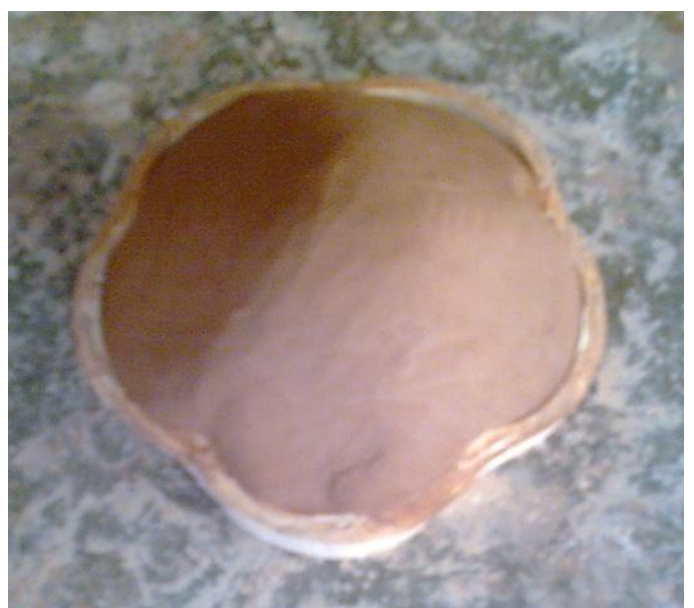

Gambar 20. Mencetak bagian atas (kelopak bunga)

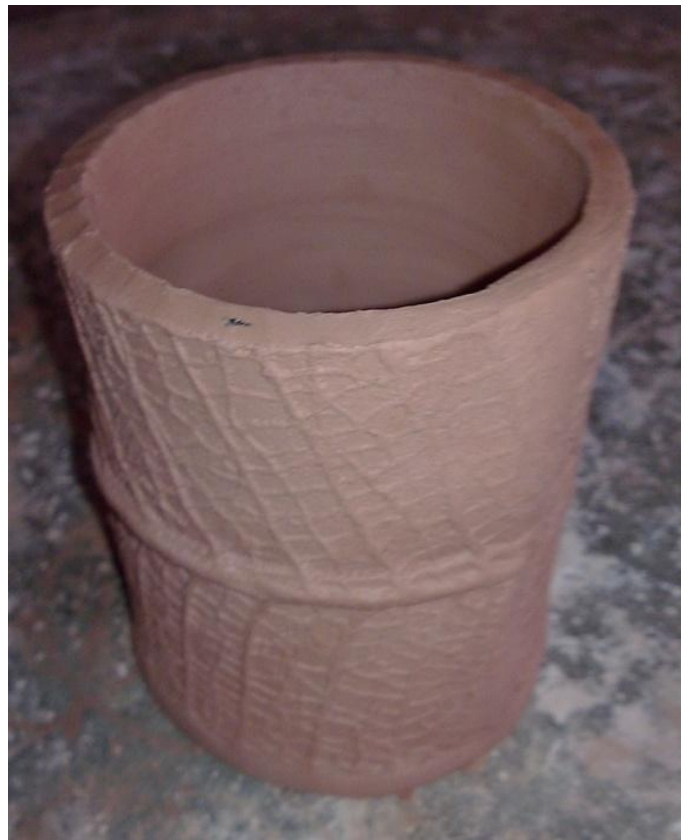

Gambar 21. Body dari tungku sebagai wadah lilinnya

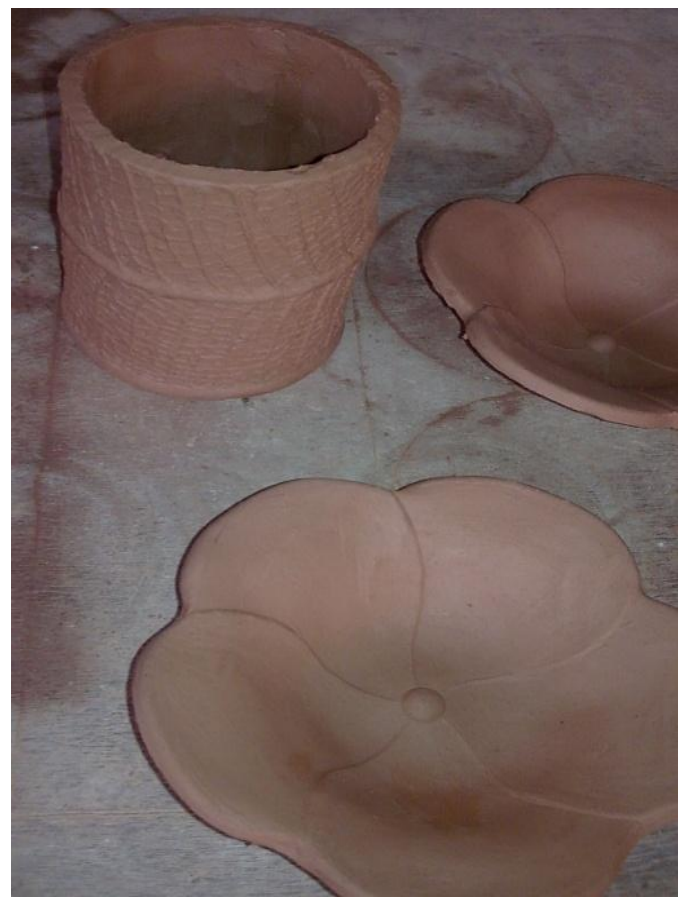

Gambar 22. Dua bagian yag akan digabungkan menjadi satu 


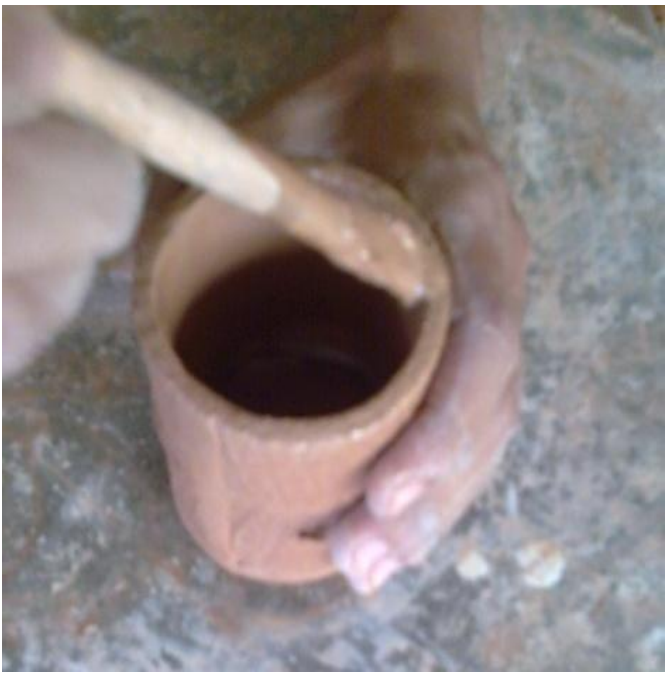

Gambar 23. Diberi lem sebelum digabungkan

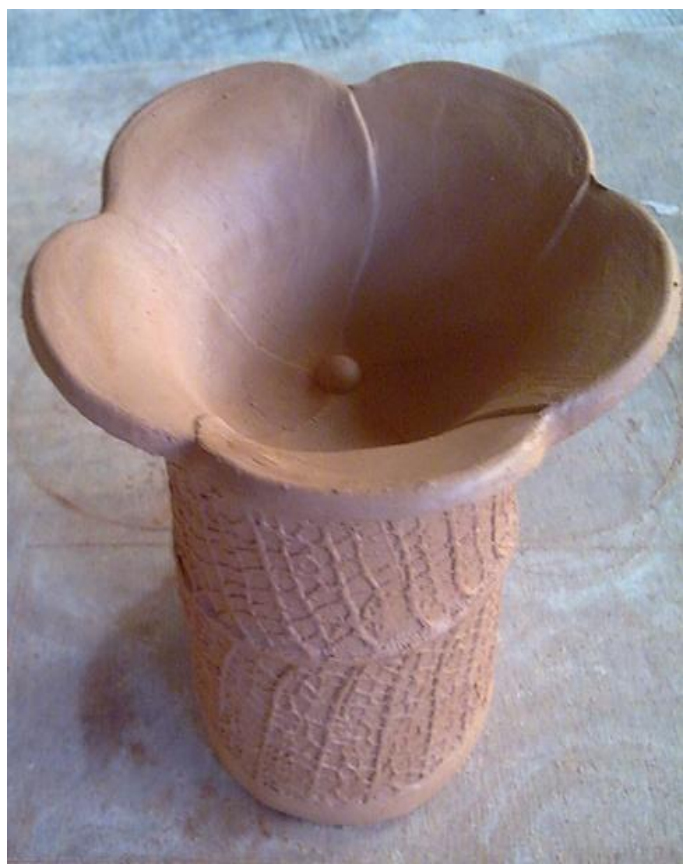

Gambar 24. Sesudah terpasang menjadi bentuk yang utuh

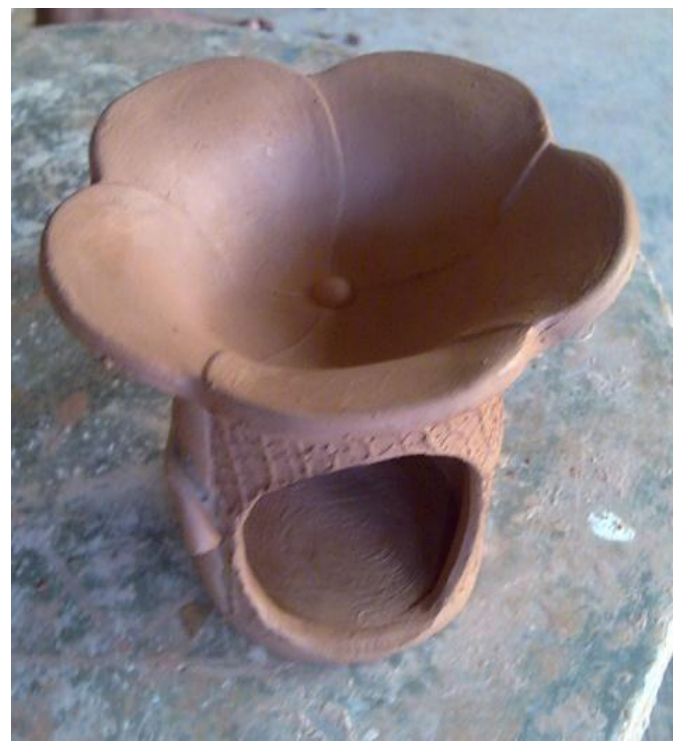

Gambar 25. Bentuk jadi , lubang untuk lilin

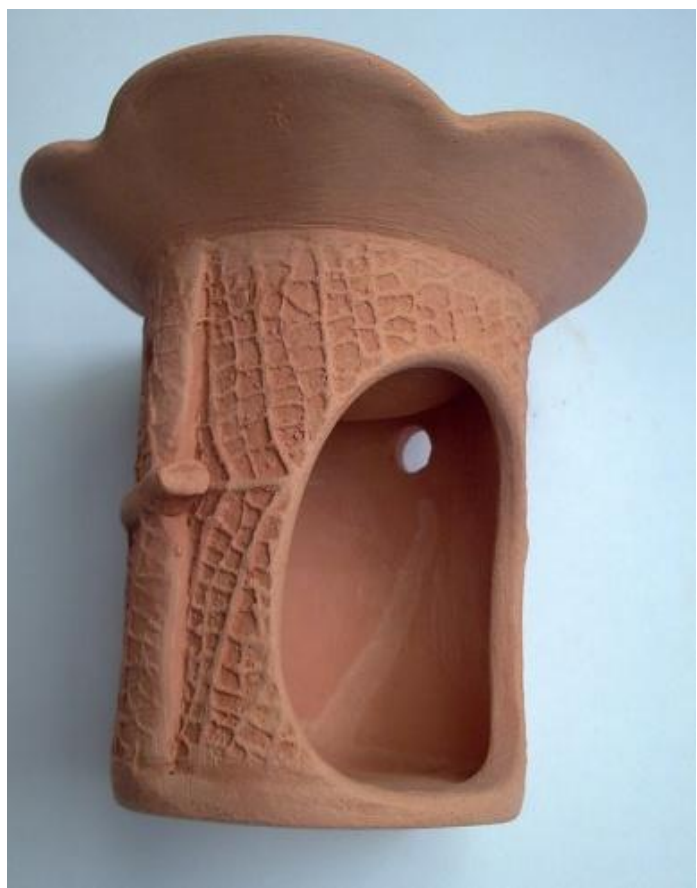

Gambar 26. Keramik bakar bisquit dengan suhu 900 derajat Celsius 


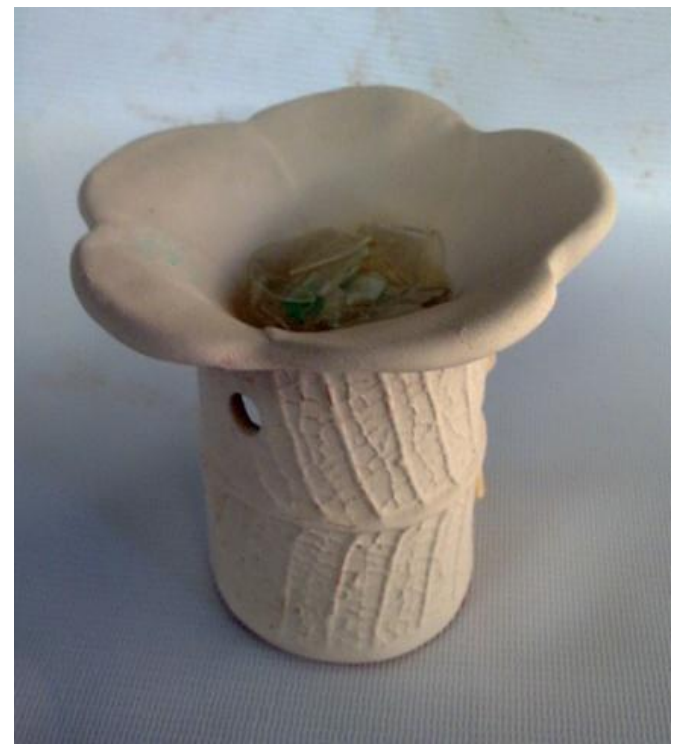

Gamabar 27. Keramik dilapisi glasir

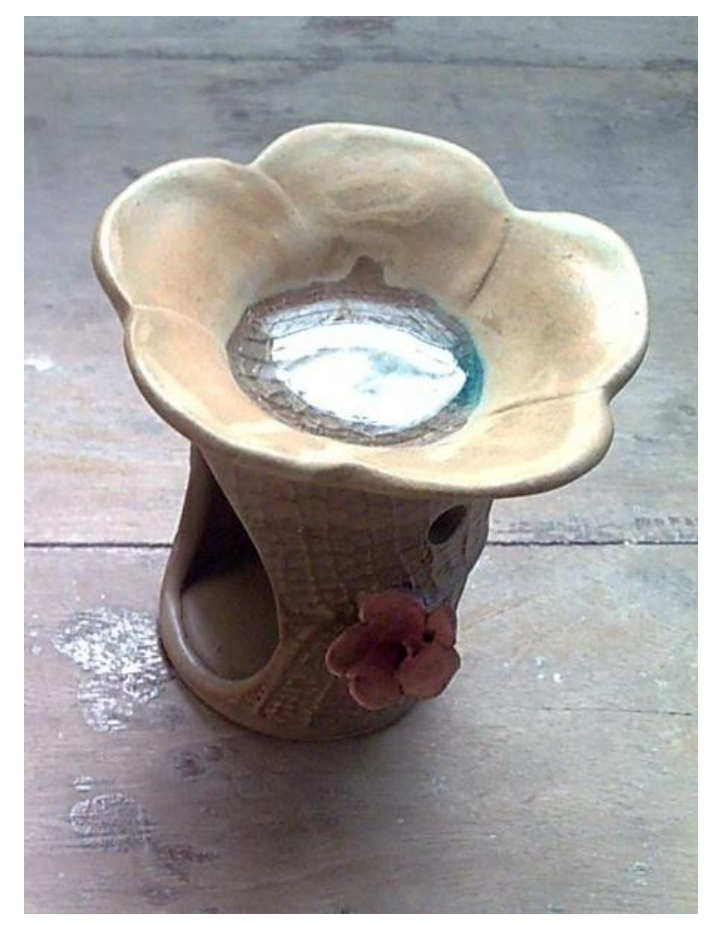

Gambar 28. Keramik suah diglasir.

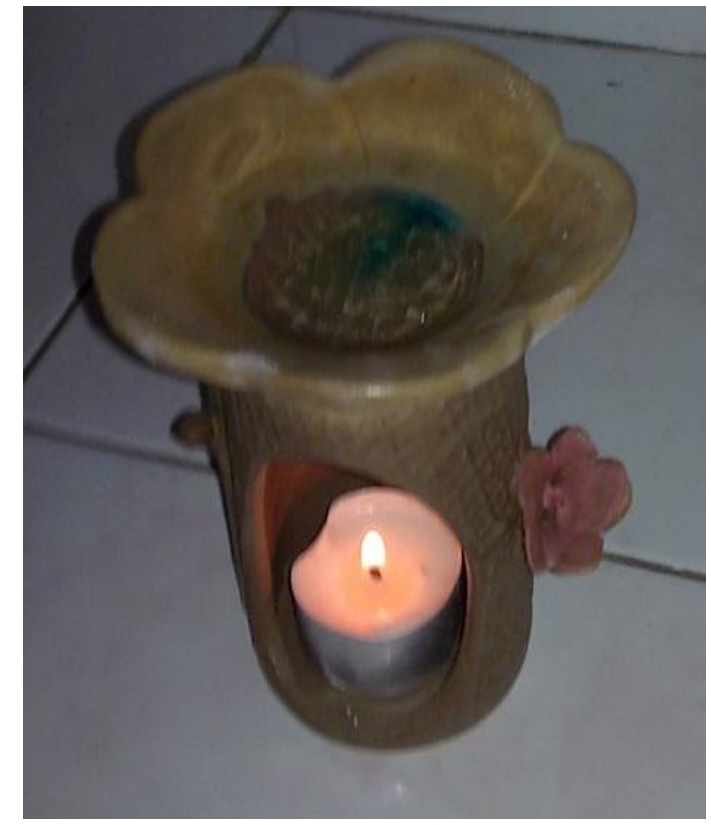

Gambar 29. Tungku Aromatherapy dengan lilinnya

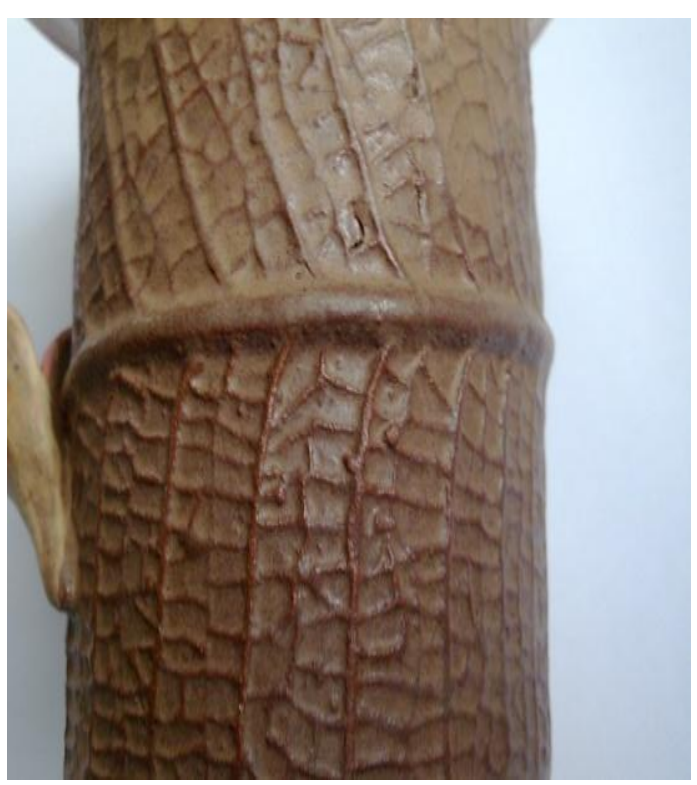

Gambar 30. Tekstur daun kamboja ditempatkan untuk body keramik

\section{DATA TEKNIS PEMBUATAN}

Pengerjaan produk atau karya tungku aromatherapy di desain oleh penulis, tungku aromatherapy bertemakan kamboja dibuat dengan tanah liat jeni stoneware, berasal dari daerah Pacitan, tanah liat plastis ini dalam pembakaran 
bisquit mencapai suhu 900 derajat Celsius selama 7jam, dengan pembakaran api balik dan bahan bakar gas elpiji. Pemabakaran glasir suhu tinggi selama 9 jam dengan bahan bakar gas, juga dilakukan dengan pembakaran api balik. Pada Tungku ini gasgas hasil pembakaran keramik mula-mula naik ke bagian atas ruang bakar, kemudian turun memanasi barang-banrang yang dibakar, kemudian keluar melalui lubanglubang pada lantai tungku ke cerobong asap melalui kanal. (Ambar Astuti: 2008.730 .

\section{PUSTAKA}

Astuti Ambar: Keramik, Ilmu dan Proses Pembuatannya, Jurusan Kriya, Fakultas Seni Rupa Institut Seni Indonesia Yogyakarta. 2008.

Don WS. Threes Emir, and Cherry $\mathrm{H}$, Memilih, Menanam, dan Merawat Kamboja, Jakarta: Gramedia Pustaka Utama. 2002.

Hidayat. Syamsul: Khasiat Herbal, Berdasar Warna, Bentu, Rasa, Aroma\&Sifat. Flona Serial. Bogor 2008.

Isworo.B.: Kamboja Bungan Halaman Gereja. Laras, VIII, November 1987. 75.

Koensumariah: A-Z Aromaterapi, Untuk Kesehatan, Kebugaran dan Kecantikan, Lily Publisher, Yogyakarta, 2011.
Sudiyati. Noor: Keramik: Ekspresi dan Teknologi, dalam Ekspresi, Jurnal Institut Seni Indonesia Yogyakarta, Seni dan Perempuan. Volume 10, 4. 2004. Yogyakarta. 2004.

\footnotetext{
Eksploitasi Daun dalam SeniKeramik, Dalam Fenomen, Jurnal Lembaga Penelitian Intstitut Seni Indonesia Yogyakarta, 2010.

Tanujaya. Alin: Sehat Ala Kaisar China, Madhara Pustaka. Yogyakarta: 2011.
}

Trimble. Stepen: Talking With The Clay, New Mexico: School of Amereican Recearch Press. 1993.

Tanujaya. Alin: Sehat Ala Kaisar China, Madhara Pustaka. Yogyakarta: 2011.

Trimble. Stepen: Talking With The Clay, New Mexico: School of Amereican Recearch Press. 1993. 